\section{Influence of Aldicarb on Growth and Fruiting of Pecan Transplants}

\author{
M. Lenny Wells ${ }^{1}$
}

AdDitional Index words. Carya illinoinensis, roots, orchard establishment, insecticide, precocity

Summary. This study was established to assess the effect of aldicarb on newly transplanted pecan (Carya illinoinensis) nursery trees. Although labeled for use on pecans for more than 25 years, the aldicarb label for pecans was voluntarily dropped by the manufacturer in 2010. Bare-root seedling, 'Cape Fear', 'Sumner', and 'Elliott' trees were planted in Feb. 2007. Ten trees each were treated with one of the following treatments: aldicarb $(0.25 \mathrm{lb}$ at budbreak), aldicarb $(0.25 \mathrm{lb}$ applied at budbreak and again in June for a total of $0.5 \mathrm{lb} /$ tree), and a nontreated control. Aldicarb increased shoot length, trunk diameter, leaf chlorophyll index, total dry weight, stem dry weight, and root dry weight of pecan seedlings after 1 year's growth. Aldicarb increased trunk diameter of 'Cape Fear', 'Sumner', and 'Elliott' during the course of the study. Nut production of 'Cape Fear' was enhanced in the third year of production. These observations indicate that aldicarb is of value in pecan orchard establishment.

$\mathrm{E}$ stablishing a pecan orchard can be an expensive and challenging endeavor. Eight years or more after transplant may be required for some cultivars to produce a harvestable yield. Rising input costs associated with fuel and fertilizer prices require an expedient return on the investment in a new orchard. As a result, cultural practices that promote early, vigorous growth may be desirable to maximize yield potential early in the life of the orchard.

Pecan trees are normally transplanted into orchards as budded or grafted cultivars on seedling rootstock. Although containerized trees are available to a limited extent, bare-root trees are used in most commercial orchard plantings in the southeastern United States. When bare-root nursery trees are dug and sold, they often lose a portion of their root system in the process. Subsequent root growth and development plays a large role in survival and growth of the tree.

Some cultivars are more vigorous and/or precocious than others (Sparks, 1992). Cultural practices that promote tree growth and vigor during the establishment phase are desirable for increasing tree fruiting surface. Numerous studies have examined the effects of planting practices, fertilizer, mulching, weed competition, and irrigation on growth of young pecan

University of Georgia, Department of Horticulture, 4604 Research Way, Tifton, GA

${ }^{1}$ Corresponding author. E-mail: lwells@uga.edu. trees (Conner, 2007; Foshee et al., 1996, 1997; Patterson et al., 1990; Smith et al., 2000, 2005; Smith and Wolf, 2001; Wood, 1996).

The systemic insecticide aldicarb has been regularly used for several years in pecan production to manage aphid populations on mature trees. Aldicarb is a carbamate pesticide withefficacy on yellow pecan aphid (Monelliopsis pecanis), black-margined aphid (Monellia caryella), black pecan aphid (Mellanocallis caryaefoliae), and pecan leaf scorch mite (Eotetranychus hicoriae) (Hudson et al., 2008). Aldicarb is applied to pecan in a soilincorporated band or shanked along the tree row. This material has been shown to stimulate growth and vigor of horticultural and agronomic crops, including sweet orange (Citrus sinensis) and cotton (Gossypium hirsutum) (Bullock and Pelosi, 1992; Reddy et al., 1997). However, no information is available in the literature regarding the effect of aldicarb on young pecan tree growth.

These experiments were undertaken to determine the effect of aldicarb on newly transplanted pecan nursery trees.

\section{Materials and methods}

SEedLING EXPERIMENT. Thirty bare-root seedling pecan trees grown from 'Elliott' seed were planted at the University of Georgia Tifton Campus Coastal Plain Experiment Station, Tifton, GA, in Feb. 2007 at a spacing of $25 \times 25 \mathrm{ft}$. Soil type was Tifton loamy sand (fine-loamy, siliceous, thermic Plinthic Paleudult). Planting holes were dug with an 18 -inch tractor-mounted auger to a depth of $3.0 \mathrm{ft}$. Trees were irrigated by drip irrigation with one 2 -gal/h pressurecompensated emitter at each tree. Ten trees each were treated with one of the following treatments: aldicarb (Temik 15G; Bayer Crop Science, Research Triangle Park, NC) $(0.25$ lb at budbreak on 23 Mar. 2007), aldicarb $(0.25 \mathrm{lb}$ applied at budbreak and again in June for a total of $0.5 \mathrm{lb} /$ tree), and a nontreated control. Aldicarb is a granular material that was applied to a concentrated area $\approx \mathrm{l} \mathrm{ft}$ from the base of each tree in the area wetted by drip emitters and was watered-in following application. Treatments were arranged in a completely randomized design. All trees were fertilized with $1 / 2 \mathrm{lb} 10 \mathrm{~N}-$ $4.4 \mathrm{P}-8.3 \mathrm{~K}$ per tree on 19 June 2007. Stem diameter measured 2.5 $\mathrm{ft}$ above the soil surface and shoot length were measured at planting and again at each of the following dates: 21 May 2007, 20 June 2007, 13 Aug. 2007, 17 Sept. 2007, and 6 Nov. 2007. Leaf chlorophyll index (LCI) was measured at each of the above dates using a chlorophyll meter (SPAD-502; Minolta, Ramsey, NJ). Measurement leaves were fully expanded and selected from one pair of middle leaflets of three compound leaves per tree. After the first growing season, trees were dug and roots were carefully washed to remove adhering soil. Stems and roots were separated

\begin{tabular}{llll}
\hline $\begin{array}{l}\text { Units } \\
\begin{array}{l}\text { To convert U.S. to SI, } \\
\text { multiply by }\end{array}\end{array}$ & U.S. unit & SI unit & $\begin{array}{l}\text { To convert SI to U.S., } \\
\text { multiply by }\end{array}$ \\
\hline 0.3048 & $\mathrm{ft}$ & $\mathrm{m}$ & 3.2808 \\
3.7854 & gal & $\mathrm{L}$ & 0.2642 \\
2.54 & inch(es) & $\mathrm{cm}$ & 0.3937 \\
25.4 & inch(es) & $\mathrm{mm}$ & 0.0394 \\
0.4536 & $\mathrm{lb}$ & $\mathrm{kg}$ & 2.2046 \\
28.3495 & $\mathrm{oz}$ & $\mathrm{g}$ & 0.0353 \\
$\left({ }^{\circ} \mathrm{F}-32\right) \div 1.8$ & ${ }^{\circ} \mathrm{F}$ & ${ }^{\circ} \mathrm{C}$ & $\left(1.8 \times{ }^{\circ} \mathrm{C}\right)+32$
\end{tabular}


$4 \mathrm{~cm}$ below the soil surface and dried at $80{ }^{\circ} \mathrm{C}$ for several weeks before weighing. Following drying, stem and root dry weights were measured.

Cultivar eXPeriment. The experiment was repeated in a commercial pecan orchard located in Berrien County, GA. Soil type was the same as that described for the previous experiment. Thirty trees each of 'Cape Fear', 'Sumner', and 'Elliot', whipgrafted onto 'Elliott' rootstock, were planted in Feb. 2007 at a spacing of $30 \times 60 \mathrm{ft}$. Planting process and experimental design were the same as that described above. Trees were irrigated with microjet sprinkler irrigation at a rate of $8 \mathrm{gal} / \mathrm{h}$ applied in a 16-ft-diameter circle. Trees were fertilized with $1 / 2 \mathrm{lb} \quad 10 \mathrm{~N}-4.4 \mathrm{P}-$ $8.3 \mathrm{~K}$ per tree on 5 June $2007, \mathrm{l} \mathrm{lb}$ $10 \mathrm{~N}-4.4 \mathrm{P}-8.3 \mathrm{~K}$ per tree on $30 \mathrm{Mar}$. and $\mathrm{l}$ June 2008, and $2 \mathrm{lb} 10 \mathrm{~N}-$ $4.4 \mathrm{P}-8.3 \mathrm{~K}$ per tree on 4 April and 3 June 2009. Stem diameter at $2.5 \mathrm{ft}$ above the soil surface and shoot length were measured at planting and again at each of the following dates along with shoot length: 21 May 2007, 20 June 2007, 13 Aug. 2007, 17 Sept. 2007, and 6 Nov. 2007. Stem diameter was measured again on 13 Nov. 2008 and 12 Nov. 2009. The number of pecan clusters and total number of nuts on each tree were counted on 16 July 2009.

Foliage was sampled on 16 July 2009 by collecting 20 leaflet pairs per tree. All leaflet samples were taken from the middle leaf of sun-exposed terminals. Leaflet samples were washed in a dilute phosphate-free detergent solution $(0.1 \%$ detergent $)$, followed by rinsing with deionized water. Leaves were then dried to a constant weight at $80^{\circ} \mathrm{C}$ and ground in a Wiley Mill (Wiley, Philadelphia) to pass a $1-\mathrm{mm}$ screen. Leaves for nitrogen $(\mathrm{N})$ analysis were also ground with a mortar and pestle. Samples were analyzed for $\mathrm{N}$ by combustion using a protein/ $\mathrm{N}$ determinator (FP528; Leco, St. Joseph, MI), whereas remaining nutrients [calcium $(\mathrm{Ca})$, magnesium $(\mathrm{Mg})$, potassium $(\mathrm{K})$, phosphorous $(\mathrm{P})$, sulfur $(\mathrm{S})$, boron $(\mathrm{B})$, zinc $(\mathrm{Zn})$, iron $(\mathrm{Fe})$, manganese $(\mathrm{Mn})$, and copper $(\mathrm{Cu})]$ were measured by an inductive coupled plasma spectrophotometer (ICP) coupled to a Digiblock 3000 (SCP Science, Baie D'Urfé, QC, Canada).
Analysis of variance was used to compare treatment effects in both studies. Cultivars were analyzed separately due to suspected differences in treatment effect between cultivars. Means were separated using Duncan's multiple range test $(P \leq 0.05)$.

\section{Results and discussion}

Young pecan trees require excellent cultural management to maximize growth and development. Practices that promote growth of pecan transplants include irrigation, transplanting early in the dormant season (Wood, 1996), and weed control (Smith et al., 2000). Systemic insecticides such as aldicarb have been used effectively in pecan to control sucking insects such as mites and/or aphids (Dutcher et al., 1984; Gentry et al., 1981; Hudson et al., 2008).

Shoot length of seedling trees was increased by aldicarb treatment on the Aug., Sept., and Nov. 2007 sampling dates (Fig. 1). By the end of the first year's growth, shoot height for seedling trees was $248 \%$ and $190 \%$ larger for the low and high aldicarb rates, respectively, than for that of the control. 'Cape Fear', 'Sumner', and 'Elliott' shoot lengths were unaffected by aldicarb treatment (data not presented).

Aldicarb increased pecan seedling trunk diameter on the Aug., Sept., and Nov. 2007 sampling dates (Fig. 2). By the end of the first year's growth, trunk diameter for seedling trees was $43 \%$ and $29 \%$ larger for the low and high aldicarb rates, respectively, than for that of the control. Cultivars were unaffected by aldicarb treatments during the year of application (data not presented). The 0.5-lb rate of aldicarb increased trunk diameter growth by $19 \%$ in the second year of study on Cape Fear; however, there was no difference in trunk diameter growth by the end of year 3 (Table 1). Two years following treatment, the $0.25-\mathrm{lb}$ rate of aldicarb increased trunk diameter growth of 'Sumner' by $18 \%$. The low rate also increased trunk diameter growth 19\% 3 years after treatment (Table 1 ). Trunk diameter growth of 'Elliott' was increased $23 \%$ and $25 \%$ by the $0.5-\mathrm{lb}$ rate of aldicarb 2 and 3 years after treatment, respectively (Table 1). It is unclear why 'Sumner' responded to the low rate of aldicarb and did not respond to the high rate. This may be a result of cultivar or rootstock differences. Previous studies in Alabama have shown growth increases of pecan trees with aldicarb at rates of less than $1 \mathrm{oz} /$ tree; however, rates of from 1 to $2 \mathrm{oz} /$ tree had no effect (W.D. Goff, personal communication).

Aldicarb increased total dry weight, stem dry weight, and root dry weight of pecan seedlings after 1 year of growth (Fig. 3). Root dry weight of trees receiving the low and high rates of aldicarb were increased by $56 \%$ and $104 \%$, respectively, over that of the control, accounting for $59 \%$ to $67 \%$ of the total tree dry

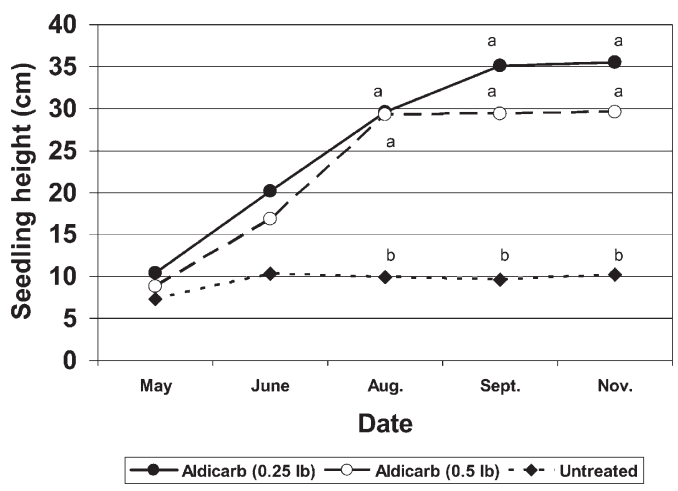

Fig. 1. Effect of aldicarb on shoot length of first-year seedling pecan tree transplants. A total of $0,0.25$, or $0.5 \mathrm{lb}$ of aldicarb was applied in the wetted area of the root zone. The $0.25-1 b$ rate was applied at budbreak. The $0.5-1 b$ application was split with $0.25 \mathrm{lb}$ applied at budbreak and $0.25 \mathrm{lb}$ applied in June. Each data point is the average of 10 single tree replications. Data were analyzed by analysis of variance with mean separation by Duncan's multiple range test. Means within date followed by the same letter are not significantly different at $P \leq \mathbf{0 . 0 5}$; $\mathrm{l} \mathrm{lb}=0.4536 \mathrm{~kg}, 1 \mathrm{~cm}=0.3937$ inch. 


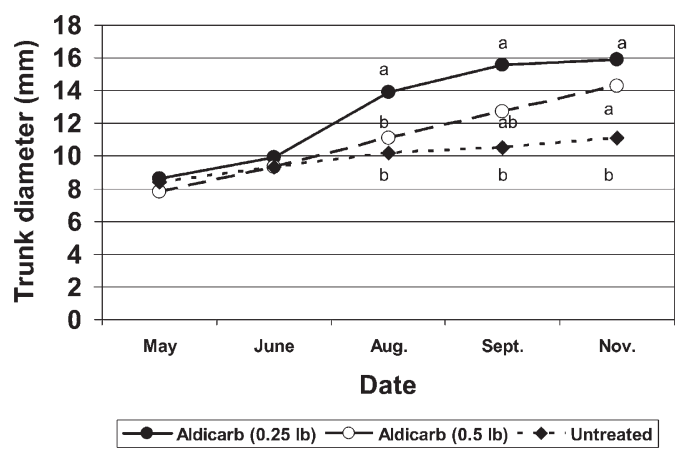

Fig. 2. Effect of aldicarb on trunk diameter of first-year seedling pecan tree transplants. A total of $0,0.25$, or $0.5 \mathrm{lb}$ of aldicarb was applied in the wetted area of the root zone. The 0.25 -lb rate was applied at budbreak. The $0.5-1 b$ rate was split with $0.25 \mathrm{lb}$ applied at budbreak and $0.25 \mathrm{lb}$ applied in June. Each data point is the average of 10 single tree replications. Data were analyzed by analysis of variance with mean separation by Duncan's multiple range test. Means within date followed by the same letter are not significantly different at $P \leq 0.05$; $1 \mathrm{lb}=0.4536 \mathrm{~kg}, 1 \mathrm{~mm}=0.0394$ inch .

Table 1. Trunk diameter growth since the planting of 'Cape Fear', 'Sumner', and 'Elliott' pecan trees as affected by aldicarb application during the year of transplanting (2007). The 0.25 - 1 b rate was applied at budbreak. The $0.5-1 b$ rate was split with $0.25 \mathrm{lb}$ applied at budbreak and $0.25 \mathrm{lb}$ applied in June.

\begin{tabular}{|c|c|c|c|c|c|c|c|c|c|}
\hline \multirow[b]{3}{*}{ Treatment } & \multicolumn{9}{|c|}{ Trunk diam growth $(\mathrm{mm})^{\mathrm{z}}$} \\
\hline & \multicolumn{3}{|c|}{ Cape Fear } & \multicolumn{3}{|c|}{ Sumner } & \multicolumn{3}{|c|}{ Elliott } \\
\hline & 2007 & 2008 & 2009 & 2007 & 2008 & 2009 & 2007 & 2008 & 2009 \\
\hline $\begin{array}{l}\text { Aldicarb } \\
\qquad(0.25 \mathrm{lb} / \text { tree })^{\mathrm{x}}\end{array}$ & $28 \mathrm{a}^{\mathrm{y}}$ & $40 \mathrm{ab}$ & $68 \mathrm{a}$ & $15 \mathrm{a}$ & $40 \mathrm{a}$ & $68 \mathrm{a}$ & 16 a & $45 \mathrm{ab}$ & $67 \mathrm{ab}$ \\
\hline $\begin{array}{l}\text { Aldicarb } \\
\quad(0.5 \mathrm{lb} / \text { tree })\end{array}$ & $28 \mathrm{a}$ & $44 \mathrm{a}$ & $73 \mathrm{a}$ & $15 \mathrm{a}$ & $38 \mathrm{ab}$ & $64 \mathrm{ab}$ & $17 \mathrm{a}$ & $49 \mathrm{a}$ & $70 \mathrm{a}$ \\
\hline Control & $26 \mathrm{a}$ & $37 \mathrm{~b}$ & $64 \mathrm{a}$ & $12 \mathrm{a}$ & $34 \mathrm{~b}$ & $57 \mathrm{~b}$ & $15 \mathrm{a}$ & $40 \mathrm{~b}$ & $56 \mathrm{~b}$ \\
\hline
\end{tabular}

${ }^{\mathrm{z}} 1 \mathrm{~mm}=0.0394$ inch.

${ }^{\mathrm{y}}$ Means followed by the same letter are not significantly different by Duncan's multiple range test at $P<0.05$. ${ }^{\mathrm{x}} \mathrm{l} \mathrm{lb}=0.4536 \mathrm{~kg}$.

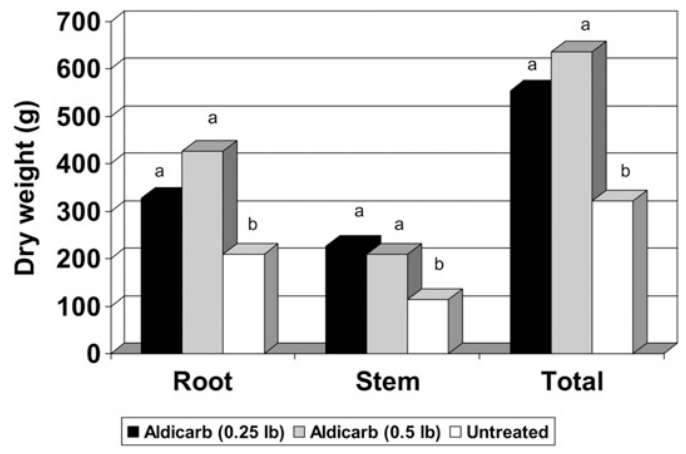

Fig. 3. Effect of aldicarb on mean root, stem, and plant dry weight of first-year seedling pecan tree transplants. A total of $0,0.25$, or $0.5 \mathrm{lb}$ of aldicarb was applied in the wetted area of the root zone. The $0.25-1 \mathrm{~b}$ rate was applied at budbreak. The 0.5 - $1 \mathrm{~b}$ rate was split with $0.25 \mathrm{lb}$ applied at budbreak and $0.25 \mathrm{lb}$ applied in June. Each data point is the average of 10 single tree replications. Data were analyzed by analysis of variance with mean separation by Duncan's multiple range test. Treatment means followed by the same letter are not significantly different at $P \leq 0.05 ; 1 \mathrm{lb}=0.4536 \mathrm{~kg}, 1 \mathrm{~g}=0.0353 \mathrm{oz}$.

weight. Increases in cotton root dry weight have been correlated with sulfoxide, a metabolite of aldicarb (Reddy et al., 1997). The authors found an increased percentage of roots at greater soil depths where aldicarb was applied. It was previously shown that aldicarb in soil rapidly converts to sulfoxide and sulfoxone, which can quickly move downward in the soil profile (Bowman, 1988). Although root distribution was not evaluated in the current study, the observed increase in pecan seedling root dry weight with aldicarb application is consistent with results obtained on cotton (Reddy et al., 1997).

Aldicarb increased the LCI of seedling trees on the Nov. 2007 sampling date from a value of 32 for the control to 40 and 39 for the low and high rates of aldicarb, respectively. Aldicarb may have reduced late-season stress, leading to higher LCI index values for treated seedling trees However, neither leaf chlorophyll index nor leaf element concentration in any of the cultivars were affected by treatment (data not presented).

The percentage of 'Cape Fear' trees with at least one nut cluster and the number of nut clusters per tree in the third year after transplant was higher for trees treated with the high rate of aldicarb than for the control (Table 2). Aldicarb did not affect nut bearing in the third year after transplant for 'Sumner' or 'Elliott' (data not presented). The difference in the varying effects of aldicarb on nut bearing between the cultivars may be explained by the increased precocity of 'Cape Fear' compared with 'Elliott' and 'Sumner' (Sparks, 1992), which could potentially allow earlier expression of the treatment effect. Only one 'Elliott' tree (which received the low rate of aldicarb) bore nuts in the third year after transplant (data not presented).

Because most of the treatment effects on seedling growth occurred from 21 May to 13 Aug., treated trees were likely able to become better established, thus increasing vigor and growth potential in subsequent years. This helps to explain the effects of aldicarb on cultivars observed in years 2 and 3 of the study. Root dry weight comprised the majority of seedling tree weight after year 1 (Fig. 3). This suggests that although no aboveground growth effects were observed for cultivars in the year of transplant, aldicarb could have affected root growth, enhancing above ground growth in subsequent years. Bullock and Pelosi (1992) showed an increase in root growth of young "Hamlin' 
Table 2. Effect of first-year aldicarb application on the percentage of nut-bearing trees and number of nut clusters per tree in the third year following transplant of 'Cape Fear' and 'Sumner' pecan trees. The 0.25 -1b rate was applied at budbreak. The $0.5-1 b$ rate was split with $0.25 \mathrm{lb}$ applied at budbreak and $0.25 \mathrm{lb}$ applied in June.

\begin{tabular}{|c|c|c|c|c|}
\hline \multirow[b]{3}{*}{ Treatment } & \multicolumn{4}{|c|}{ Cultivar } \\
\hline & \multicolumn{2}{|c|}{ Cape Fear } & \multicolumn{2}{|c|}{ Sumner } \\
\hline & $\begin{array}{c}\text { Trees bearing } \\
\text { nuts (\%) }\end{array}$ & $\begin{array}{c}\text { Nut clusters } \\
\text { (no./tree) }\end{array}$ & $\begin{array}{c}\text { Trees bearing } \\
\text { nuts (\%) }\end{array}$ & $\begin{array}{l}\text { Nut clusters } \\
\text { (no./tree) }\end{array}$ \\
\hline $\begin{array}{l}\text { Aldicarb } \\
\quad(0.25 \mathrm{lb} \text { per tree })^{\mathrm{y}}\end{array}$ & $10 b^{z}$ & $0.1 \mathrm{~b}$ & $20 a$ & $0.2 \mathrm{a}$ \\
\hline $\begin{array}{l}\text { Aldicarb } \\
\quad(0.5 \mathrm{lb} \text { per tree })\end{array}$ & $67 a$ & $1.6 \mathrm{a}$ & $30 \mathrm{a}$ & $0.4 \mathrm{a}$ \\
\hline Control & $30 \mathrm{~b}$ & $0.4 \mathrm{~b}$ & $10 \mathrm{a}$ & $0.2 \mathrm{a}$ \\
\hline
\end{tabular}

${ }^{2}$ Means followed by the same letter are not significantly different by Duncan's multiple range test at $P<0.05$. ${ }^{y} \mathrm{ll}=0.4536 \mathrm{~kg}$.

orange trees when aldicarb was applied to young trees. Their results also demonstrated a shorter interval to productivity and higher production at tree maturity with aldicarb. Reddy et al. (1997) suggested a direct regulatory effect of aldicarb on cotton growth in the absence of pests. No direct measurements of insect populations were taken in our study; however, aphid populations were not observed to be a problem in any treatment at either location. Although it is unclear at this point whether the effect of aldicarb on pecan tree growth is due to the indirect effect of aphid control or a result of a direct response of the pecan tree to aldicarb, the observed increase in seedling tree root dry weight in the aldicarb treatments and lack of insect pressure in all treatments during the current study supports a potential direct effect of aldicarb on pecan tree growth independent of insect induced stress.

Although location differences, including spacing and irrigation methods, could have played a role in the outcome of the studies, the seedling and cultivar experiments were considered separate studies by the authors due to expected variation in treatment response between seedlings and improved cultivars. As a result, location effects were not evaluated. Spacing differences between the seedling and cultivar studies are not suspected to have led to any observed differences because shading and root competition were not considered significant factors with young trees at the spacings described. Similarly, although differences in irrigation methods between the two experiments could potentially have affected the outcome of the study, this is not suspected. Aldicarb was applied to the wetted area within the root zone of all trees in both experiments, which would have allowed for effective uptake.

In summary, aldicarb appears to be of value in its potential for enhancing growth and, perhaps in some cultivars, early nut production of young pecan tree transplants. It appears that aldicarb can potentially influence early fruiting potential of 'Cape Fear'; however, this cannot be determined conclusively from data generated only in the first year of fruiting. It is reasonable to conclude that because fruit production is generally considered a function of tree size, earlier fruiting could be an indirect effect of aldicarb application through enhanced tree growth rather than through direct stimulation of fruiting by aldicarb. Although labeled for use on pecans for more than 25 years, the aldicarb label for pecans was voluntarily dropped by the manufacturer in 2010 . If aldicarb were to once again be labeled for pecans, it could help enhance young pecan tree growth and orchard establishment.

\section{Literature cited}

Bowman, B.T. 1988. Mobility and persistence of metalochlor and aldicarb in field lysimeters. J. Environ. Qual. 17: 689-694.

Bullock, R.C. and R.R. Pelosi. 1992. Influence of Temik aldicarb soil treatments on growth of newly planted 'Hamlin' orange trees. Proc. Intl. Soc. Citriculture 3:991-994.

Conner, P.J. 2007. Effect of nitrogen fertigation on first-year pecan seedling growth. HortTechnology 17:491-495.

Dutcher, J.D., R.E. Worley, J.W. Daniell, R.B. Moss, and K.F. Harrison. 1984. Impact of six insecticide based arthropod management strategies on pecan yield, quality, and return bloom under four irrigation/soil fertility regimes. Environ. Entomol. 13:1644-1653.

Foshee, W.G., R.W. Goodman, M.G. Patterson, W.D. Goff, and W.A. Dosier. 1997. Weed control increases yield and economic returns from young 'Desirable' pecan trees. J. Amer. Soc. Hort. Sci. 122:588-593.

Foshee, W.G., W.D. Goff, K.M. Tilt, J.D. Wiiliams, J.S. Bannon, and J.B. Witt. 1996. Organic mulches increase growth of young pecan trees. HortScience 31: $811-812$.

Gentry, C.R., J.A. Payne, and R.A. Simonaitis. 1981. Soil treatment with aldicarb against several insect pests of pecans. J. Entomol. Sci. 16:257-260.

Hudson, W., J. Brock, S. Culpepper, and L. Wells. 2008. Georgia pecan pest management guide. Univ. Georgia Coop. Ext. Bul. 841.

Patterson, M.G., G. Wehtje, and W.D. Goff. 1990. Effects of weed control and irrigation on the growth of young pecans. Weed Technol. 4:892-894.

Reddy, V.R., K.R. Reddy, and Z. Wang. 1997. Temperature and aldicarb effects on cotton root growth and development. Biotronics 26:1-11.

Smith, M.W. and M.E. Wolf. 2001. Allelopathy of bermudagrass, tall fescue, redroot pigweed, and cutleaf evening primrose on pecan. HortScience 36 : 1047-1048.

Smith, M.W., B. Carroll, and B.S. Cheary. 2000. Mulch improves pecan tree growth during orchard establishment. HortScience 35:192-195.

Smith, M.W., B.S. Cheary, and B.L. Carroll. 2005. Temporal weed interference with young pecan trees. HortScience 40:17231725.

Sparks, D. 1992. Pecan cultivars: The orchard's foundation. Pecan Production Innovations, Watkinsville, GA.

Wood, B.W. 1996. Establishing pecan transplants. HortTechnology 6:276-279. 